\title{
ACROSTALAGMUS APHIDUM OUD. AND APHID CONTROL
}

\author{
J. A. B. NOLLA \\ Assistant Plant Pathologist, Insular Experiment Station
}

The control of aphids through fungous parasitism has attracted much attention during the last two decades. Johnston (1) was the first one to call attention to the existence of fungi on aphids in Porto Rico, which he regarded as important in the control of this pest. The present paper deals with a study of Acrostalagmus aphidum oud. with special reference to its use in the control of some plant lice.

In 1915 Jones (3) reported the fungus Acrostalagmets albus Preuss. on the sugar cane aphid Sipha flava Forbes. During the same year Jolmston (2) in his description of the entomogenous fungi of Porto Rieo gave this fungus on various hosts. In 1926, the writer's attention was called to the parasitizing action of this fungus on the aphids of the melon in a planting in the interior" of the island. Preliminary studies were made that year. These were followed by more extensive field trials in 1927 and 1928. Because the fungus and been reported in Porto Rico under the name of Acrostalagmus albus, and the description did not agree with that offered in saccardo for that species, inaterial was sent to the Inited States Department of Agriculture Bureau of Plant Industry for determination. Miss Vera $K$. Charles of that Burean, after a comparison with a number of species of Acrostalagmus concluded it was A. aphidum Oud. and not A. albus Preuss. It should be noted that Jolmston (2) had found considerable difference between the type and his Porto Rican form but regarded it as "scarcely enough to indicate a separate species." Although the writer finds differences between the morphology of the Porto Rican form and the description in Saccardo, which may be considered enough to erect at least a distinet variety or strain he has retained the name Acrostalagmus aphidum. Oud.

A study of the fungus has been made both on its natural and on artificial strata. Normally a profuse white to creamy mycelium develops on the surface of the parasitized insects. The mycelial threads are slender, siphonaceous, mostly dichotomously branched. Asexual spores are abundantly produced on erect fertile hyphae. 
These spore-bearing threads are occasionally septate but more usually continuous. They fork out into three to four branches two or three of which bear spores at the tips and one usually grows out and branches again giving rise to more condiophores (see Plate XI, fig. 10). The usual number of these branches is three. Conidia are borne singly or in heads (see Plate XI, fig. 7-10). They are oblong, cylindrical or elliptical, obtuse on both ends or slightly pointed at one, hyaline, non-septate; the size of the Porto Rican form varies from 3-14 $\times 1-4$ microns, and has a mean of $7.259 \pm 0.0717 \times$ $2.47 \pm 0.02$ microns. The exact manner of head formation has not been clearly established. From observations of germinating spores if seems that the spore heads are formed as follows: The first conidium formed becomes detached from the tip but does not fall off. It seems to be enveloped by some sort of a mucilaginous substance which prevents it from falling off. A second conidium is produced at the tip, and others follow in succession all remaining together in a head-like structure held by an apparently evanescent film (see Plate XI, fig. 8).

Measurements of conidia were made from various hosts. The differences found in the size of the spores from the various natural strata (different species of aphids) are insignificant. Some of the results appear in Table $\mathrm{I}$.

TABLE I

LENGTHS AND WIDTHS OF CONIDIA IN MICRONS-FUNGUS ON THREE DIFFERENT STRATA

\begin{tabular}{|c|c|c|c|c|c|c|c|c|}
\hline \multirow[b]{2}{*}{ Stratum } & \multicolumn{4}{|c|}{ Lengths } & \multicolumn{4}{|c|}{ Widths } \\
\hline & 貣 & $\begin{array}{l}\text { 音 } \\
\text { 恖 } \\
\text { 总 }\end{array}$ & $\begin{array}{c}\text { Modal } \\
\text { class }\end{array}$ & Mean & 音 & 离 & $\begin{array}{c}\text { Modal } \\
\text { class }\end{array}$ & Mean \\
\hline Okra aphid ...... & 3.95 & 11.84 & 6.0 & $\begin{array}{r}7.055+ \\
0.0699\end{array}$ & 1.32 & 3.42 & 3.0 & $\begin{array}{r}2.616+ \\
0.271\end{array}$ \\
\hline Eggplant aphid... . & 3.45 & 13.11 & 7.0 & $\begin{array}{r}7.259+ \\
0.0717\end{array}$ & 1.04 & 3.45 & 2.5 & $\frac{2.47+}{0.020}$ \\
\hline Oatmeal agar. & 3.16 & 10.52 & 6.0 & $\frac{6.028+}{0.055}$ & 1.32 & 2.63 & 2.0 & $\begin{array}{c}2.265+ \\
0.022\end{array}$ \\
\hline
\end{tabular}

A biometrical consideration of the results indicates that the difference in mean spore lengths in the fungus growing on the boclies of the eggplant aphid and that on the oatmeal agar is significant, 
about thirteen times its error; as is the difference between the okra aphid fungus and the fungus on the oatmeal agar, its error being contained in it about 11 times. On the other hand the little difference between the okra aphid and the eggplant fungus spore mean lengths falls within the limits attributed to random sampling. In the mean widths of spores, however, it appears that there is only a significant difference, seven times its error, between the fungus on the eggplant aphid and the culture on oatmeal agar. Here the greater mean width is found in the former and agrees with the results on lengths of spores.

A further consideration of the figures on the table shows that our measurements vary somewhat from those given in the original deseription for A. aphidum Oud. Thus, there the size of conidia is given as $7-14 \times 2.5$ microns. Our results show a wider range of spore length and width. From the table we find that the measurements for the Porto Rican fungus are $3-14 \times 1-4$ microns with a mean size of $7.259 \pm 0.0717 \times 2.47 \pm 0.02$ microns.

The description of the fungus is here inserted as taken from Saccardo's "Sylloge Fungorum":

"Acrostalagmus aphidum Oud. Beitr. Bot. Centr. 1902, p. 15. Syll. 18:536-37. Caespitibu's effusis, tennibus, albis, hyalinis; hyphis sterilibus repentibus, ramosis, continuis; fertilibus erectis, sursum trifucatis, ramis secundariis primario aequilongis $v$. longioribus, continuis, summo subulato, capitulo conidior'um capitato-aggregatorum, muco conglutinatorum 12-16 micr. diam. one-ratis; conidiis oblongis, hyalinis, continuis, eylindraceis, rectis, utrinque obtusis, $7-14 \times 2.5$.

Hab. in sceletis Aphicleae eujusdam, in superficie foliorum Aristolochiae gigantis in holto botanico Utrecht Hollandiae."

Nederl. Kruidk. Arch. Sel. 3, Vol. 2, p. 759 (1902)

Acrostalagmus aphidum Oud.-Sur les squelettes aceumulées d'une Aphidée, a la surface des feuilles languissantes d'un Aristolochia gigas, cultivé dans une serre chaude du Jardin botanique d'Utrecht, le 13 Oct. 1900.-Mr. A. Pulle, candidat en histoire naturelle.-Touffes épar'ses, subtiles, blanches, hyalines sous le mieroscope. Hyphes steriles rempantes, rameuses, eontinues; fertiles dressées, trifurquées au sommet, a branches aussi longues ou plus longues encore que la hyphe-mére, continues, pourvues a leur sommet subule d'une agglomération sphérique de conidies, retenues en place par une matiére glutineuse, large de 12 a 16 p. Conidies nombreuses, oblongues, hyalines, continues, droites, arrondies anx bouts, $7-14 \times$ $2-1 / 5$.

Spore gesmination.-Studies were undertaken with the object of 
finding out the optimum conditions for spore germination. In all cases fresh spores were used as the results would give an approximation to what occurs in nature. Drops from a spore suspension in tap water were placed on sl.des and kept in a moist chamber. In another set the drops were placed in Van Tieghem cells and likewise placed in a moist chamber. Observations showed that the germ tubes began to protrude at the ends, after two hours and forty minutes. A count of the spores that had germinated and those that had not was made at the end of six and one-half hours. Of 884 spores counted in the drops on the slides, 604 germinated and 280 failed to do so. This shows a 68.33 per cent of viable conidia.

It has becn olsserved that some of the con dia become one-to several-septate prior to or after germination. At the end of several hours of germination, conidia are producerl at the tips of the branches of the fertile hyphae. In some of the branch tips a bulged-out affair is only formed with no evidence of the conidia. Some of these structures have been seen to function in germination like the conidia (see Plate XI, fig. 7). The heads are soon formed and at the end of ten or twelve hours may contain as many as four or five spores. Some of the young conidia will germinate while still attached to the headlike fruiting strueture (Plate XI, fig. 6).

It was observed that some germinating conidia send out dark structures at the end of the germ tubes, which resemble and function like the appresoria of the antluracnoses (Plate XI, fig. 5). These secondary bodies and the germ tubes which bear them become brown. They have always been found where the moisture present during the early stages of germination was lost and therefore development was temporarily arlested. When moisture is restored these germinate by sending out long germ tubes or short, fertile branches. This again likens; them to the appresoria of some of the Melanconiales.

Germination in sugur solutions.-Suspension of fresh spores were prepares on 10 per eent sucrose and 10 per ecnt glucose solutions and in clistilled water. Drops were placed on slides and allowed to germinate in the usual manner. Germination started simultaneously in the check and the two sugar solutions. Counts made at the end of five hours showed that 78.365 per cent of the spores in distilled water, 89.795 per cent in the snerose solution and 97.80 per cent in the glucose solution had germinated. Undoubtedly there was a marked favorable effect of the glucose on germination. Germination was somewhat higher in the sucrose solution than in clistilled water. Although the lengths of the germ tubes were not measured at the 
time, it was clear to the writer that the much longer germ tubes were found on the spores germinating in the glucose solution.

Dessication of spores.-To determine the effect of drying on conidia, a suspension of these was made in distilled water and drops placed on slides. The drops of water were dried from the slides by operating an electric fan. Two slides were left without drying the water film and the spores allowed to germinate in a moist ehamber. These served as a check. The slides with the dried films of water were divided in two sets, one of which was placed in dry chambers and the other in moist chambers. 'Tests for viability of the conidia were made on the following day. Upon examination of the slides in the moist chambers it was found that a considerable number of the conidia had germinated. The same thing happened in the ehecks. By the third day most of them had sent out germ tubes.

In the dry chamber set, the germinating power of the spores was rap dly lost. On the third day only about 33 per cent were vable; while on the fifth day only 8 per cent retained the germinating ability and on the sixth day none of the spores germinated. It is thus demonstrated that spores germinate readily in the presence of a small quantity of moisture and that their germinating power is hindered by dessieation, retaining their ability to germinate for only five days in the absence of moisture.

Effect of aphid extracts on germination.-To aseertain whether extracts of the insect juices had any effect on the rate of germination of conidia, a considerable number of aphids from two hosts were gathered, macerated and the extract obtained in distilled water. The small portions of the bodies of the insects were removed from the extracts. A suspension of fresh spores was then made in each of the two extracts and indistilled water. Drops were placed on slides and those in germinating chambers. The lengths of the conidia and germ tubes were measured at the end of six and one-half hours. The results are given on Table II.

Table II

IENGTHS IN MTCRONS OF GERMINATING CONIDIA ON VARIOUS MEDIA

\begin{tabular}{|c|c|c|c|c|}
\hline \multirow{2}{*}{ Extract of } & \multicolumn{4}{|c|}{ Lengths } \\
\hline & Minimum & Máximum & Mode & Menn \\
\hline Cryptostcgia aphid.. & 13.80 & 124.20 & 24.15 & $41.45+0.795$ \\
\hline Cyporus aphid. & 10.35 & $\$ 6.25$ & 24.15 & $29.60+0.5882$ \\
\hline Distilled water. & 9.35 & 62.10 & 13.80 & $19.159+0.2511$ \\
\hline
\end{tabular}


A glance at the table makes evident that a pronounced difference in mean length of tubes exists on germination spores in aphid juices as compared to distilled water. This difference is abont 10.44 microns for the spor'es on the Cyperus aphid juice and is about sixteen times its error. The difference between the mean lengths of germ tubes in the Cryptostegia aphid juice and distilled water is 22.291 microns which is nearly twenty-seven times its error and therefore highly significant. Further, the difference of mean lengths of tubes in the two juices is 11.85 microns, abont twelve times its error. The mean lengths are significant to the point of indicating a stimulating effect of aphicl juices on germination and suggesting variations in this influence according to the species of aphids. (See PJate XI, fig. 1-4).

Effect of reaction on growth of the fungus.-The fungus was grown in Bouillon and in a culture solution No. 1 * of pH values ranging from 2.94 to 9.44 . The results are given in Table III.

TABLE III

EFFECT OF REACTION ON GROWTH OF A. APHIDUM

\begin{tabular}{|c|c|c|}
\hline $\mathrm{pH}$ & Solution No. 1 & Bouillon \\
\hline 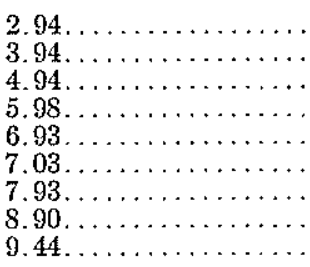 & $\begin{array}{c}- \\
++ \\
+++ \\
++++ \\
++++ \\
++++ \\
+++ \\
++\end{array}$ & $\begin{array}{l}+-- \\
+\frac{1}{+} \\
++ \\
+++ \\
+++ \\
+++- \\
++ \\
+-\end{array}$ \\
\hline
\end{tabular}

In the table degree of luxuriance of growth is represented by crosses, four + 's standing for optimum development and + - for slight growth. This organism seems to produce optimum growth in media of the reaction 6.93 to 7.93 , from almost neutral to slightly alkaline. Growth ceases in acid concentrations of pH 2.94 and only a slight development occurs in reactions of pH 9.44 .

\section{Fosts}

As has been stated before the pathogene was reported on Sipha flava (3). In 1915 Johnston (2) reported the fungus on the following hosts: Sipha graminis on Saccharum officinarum L., the Eupatorium odoratum aphid, and the dead bodies of the aphid on okra

\footnotetext{
* Formula. Cane sugar 60 gms., ammonium phosphate 0.6 gms., magnesium sulphafe 0.25 gms. ferrous bulphate trace, and water to make 1,500 c. c. Renction adjusted to lower concentrations with tartaric acid.
} 
(Abelmoschus esculentus, (L) Moench.). It seems that Johnston made a slight error in giving the sugar-cane aphid as Sipha gramins. Stevenson (4) in 1918 added Corythaica monacha on Solanum melongena to the list of hosts given above.

Wolcott (5) cites Van Zwaluwenburg (6) as leporting A. albus on the eoffee aphid Toxoptera aurantite. Boyer. Table IV gives a :ummary of the hosts of this pathogene in Porto Rico.

A number of the host plants of the aphids are marked with one or two stars while others are unmarked. Those plant hosts with one star had been reported previously, those with two stars are first recorded here while on those without any star the fungus has not been found or reported as yet. The genera and species of aphids with one star are those first found by the writer to be parasitized by the fungus

\section{TABLE IV}

HOST RELATIONSHIPS OF A. APHIDUM

\begin{tabular}{|c|c|}
\hline HOST OF THE FUNGUS & PLANT MOST \\
\hline Aphis gossypii Glover & 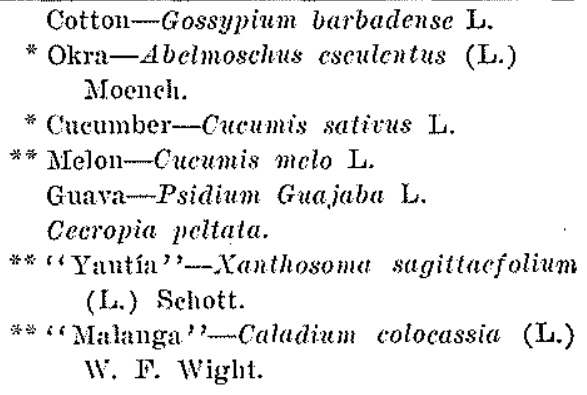 \\
\hline Rhopalosipham porsicae Sulzer & $\begin{array}{l}\text { "Eggplant-Solanum melongcna } \mathrm{L} \text {. } \\
\text { * Pepper-Capsieum baccatum } \mathrm{L} \text {. } \\
\text { Sweet potato-Ipomoca batatas } \mathrm{L} \text {. } \\
\text { Sesame-Sesamum oricutale } \mathrm{L} \text {. }\end{array}$ \\
\hline Toxoptera auriantiae Boyer & 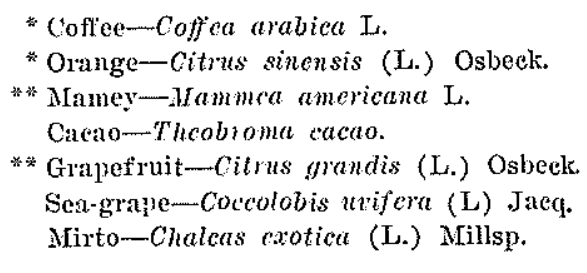 \\
\hline Sipha flava Forbes & $\begin{array}{l}\text { * Sugar-eanc-Sacharum offcinarum } \mathrm{I} \text {. } \\
\text { Sorghum-Holcus sorghum } \mathrm{L} \text {. } \\
\text { Lemon grass-Cymbopogon citratus } \\
\text { (DC) Stapf. }\end{array}$ \\
\hline
\end{tabular}


HOST RELATIONSHIPS OF $A, A P A I D D M$-Continued

\begin{tabular}{|c|c|}
\hline HOST OF THE FUNGUS & PLANT IIOST \\
\hline $\begin{array}{l}\text { Corythaica monacha Stal. } \\
\text { (eggplant lace-bug) }\end{array}$ & ${ }^{*}$ Egoplant-Solanum melongena L. \\
\hline * Aphis pseudobrassicae Davis & $\begin{array}{l}\text { ** Cabbage-(Brassica cleracea L.) } \\
\text { Mrustard- (B. integrifolia (West) O. E } \\
\text { Seluulz) }\end{array}$ \\
\hline $\begin{array}{l}\text { * Carolinaia oyperi Ainslie. } \\
\text { Undetermined aplid } \\
\text { Undeternined aplid }\end{array}$ & $\begin{array}{l}\text { * "Coqui" —Cyperus rotundus } \mathrm{L} \text {. } \\
\text { * Cryitostcqia madtagascariensis } \\
\text { * Eupalorilim odoratum }\end{array}$ \\
\hline
\end{tabular}

Inoculation experiments.-The first work done with this problem was in December of 1926 . At that time there oceurred a very heavy infestation of the aphid Rhopalosiphum persicae on eggplants which were being grown for breeding purposes. The writer diseovered a number of plants the leaves of which showed on the under surface an abuntance of small white, cushony-like masses, which upon closer examination proved to be dead bodies of aphids covered with mycelium of the Acrostalagmus fungus. Simultaneously the writer had collected melon leaves in Cayey, P. R., which also showed the parasitized bodies of aphids. Cultures were made from the dead bodies of both the melon and eggplant aphids. Cucumber and eggplant seedlings were grown in pots in the green house. When the eggphant: had attained a he ght of eight inches and the cucumber vines were about two feet in length they were exposed for a day in places where it was known infestation of each host would come about. When the plants showed the aphids on the lower surfaces of the tender leaves they were removed to the greenhouse with care not to shake off the plant lice. There the insects were allowed to multiply. The plants were next put inside cages (cheese cloth-lined) and here sprayed with a suspension of the Acrostalagmus spores. 'This operation was performed on an evening just before sunset. Spores of the fungus both from dead aphids and from corn meal agar cultures were employed." There were in the experiment three sets of eggplant and three of cucumber plants. In each case one set was left as check, a second one sprayed with spores from the corn meal agar culture and the third received the suspension of spores from the fungus growing on dead aphids. After inoculation the cages were kept moist for two days so as to insure adequate moisture relations for the germination of the spores. Daily observations were made. At the end of the third day a few aphids in each inoculated cage were found to show a slight brownish discoloration (not the browning 
induced by the insect hyperparasites). The number of dead insects increased every day until the end of one week when the majority had suceumbed to the attacks of the pathogene. In fourteen days a'1 the aphids in the inoculated eages had died. This experiment demonstrated that either the melon or eggplant aphid fungus had the ability of parasitizing the aphids on either the eggplant or cueumber. The cucumber and the melon aphids are identical. That the melon aphid fungus and the eggplant aphid fungus were one and the sane was corroborated by further cross-inoculations on pepper, eggplant, cucumber and melon, and by microscopic examination. The aphid on the eggplant and pepper is the same species. The details of these inoculations are omitted because the method is the same as described above.

It was planned to inoculate as many species of aphids and on as many hosts as conld be found in abundant numbers or could be grown in the greenhouse. In November 1927, a number of sprouts arising from a "mamey" (Mammea americana) stubble exhibited a curly appearance of their more tender leaves. Upon examination they were found to be covered on the under surface by a considerable number of plant lice. These were soon sprayed on a cool afternoon with a suspension of the spores of Acrostalagmus. Death of the inseets was brought about in from six to twenty days. 'l'his is a new record of parasitism of the fungus on the species which had been reported (6) as attacked on coffee and orange.

In the month of December of that year the fungus was found on okra (Abelmoschus esculentus), and again on the melon aphid, on eggplant, pepper and cucumber. Inoculations from each of these were performed on the eggplant aphid with successful infection. The aphid on the okra was also inoculated with the fungus isolated from the dead insects on this host and it also died.

The fungus made its reappearance during the months from October to February (1928-29) on the aphids on the following plants: eggplant, pepper, cueumber and okra. New isolations were made this year and used in the inoculations which are given later.

In December, 1928, a number of "coquí" (Cyperus rotundus) plants were examined for the presence of aphids. It was discovered that a number of the insects had been killed by a whitish fungus and Acrostalagnus aphidum was suspected as the causal agent. Isolations were made and the cultures employed in cross-inoculation studies.

A search was made for different species of aphids and on different hosts. In January we cliscovered abundant aphids on the following 
hosts: egrglant, cabbage, (Brassica oleracea L.), mustard (B. integrifolia (West) O. E. Schulz), "coquí" (Cyperus rotundus), "yautía" (Xanthosoma sagittaefolium (L.) Schott), "malanga" (Caladium colocassia (L.) F. W. Wight, Cryptostegia madagaseariensis (a recent introduction from the botanical garden of Panama, Central America), on grapefruit (Citrus grandis (L.) Osbeck and on corn (Zea Mays L.). All the aphids on these hosts were inoculated with a suspension of the spores of the fungus isolated from the eggplant aphid. The "coquin" aphid was in addition sprayed with the spores of the eulture obtained from the dead aphids on this host. All the aphids except those on corn were killed by the fungus.

The results of these inoculations prove the similarity or identity of the Cyperus rotundus aphid fungus and the eggplant aphid Acroslalagmus, because the Cyperus aphid is killed by both fungi. The results also add aphids of two other genera and an undetermined one on four plant hosts to the list of suscepts of A. aphidum. The fungus has been shown to infect the aphid Toxoptera auriantiae Boyer on two other hosts (grapefruit and "mamey"), which the aphid may attack. (See Table I.)

The fungus did not kill the corn aphid under natural conditions. Mr. Sein, the Assistant Entomologist showed to the writer a number of corn aphids which he had kept in a enlture dish and which happened to be covered with a whitish mycelium, similar to that of $A$. aphidum. A microscopic examination showed the fungus to be $A$. aphidum. Further trials were therefore made with this aphid. A small number, about 30 , of insects with a few fragments of corn leaves were put in each of two large culture tubes $(200 \times 25 \mathrm{~mm}$.) About 4 c. c. of a suspension of spores of the fungus were added to one of the tubes. The tube was kept under fair conditions of humidity by a piece of moist cotton which hung from the mouth. The mouth of the tube was stopped with a donble thickness of cheese-cloth. Observations were made daily. At the end of six days all the aphids were alive in the two tubes. At the end of ten days no more corn-leaf fragments were put in the tubes. Twelve days after the experiment was started a large number of aphids had died in both tubes. It was then that the fungus mycelium was first appearing on the dead bodies of the aphids from the inoculated tube. We interpret these results as indicating that the fungus is not eapable of parasitizing the corn aphid but that it may live on the dead bodies of the insect in a saprophytic manner. Had the death of the insects been brought about by the infection produced by the 
fungus then we would have expected some dead bodies in four to eight day, as is the case in the susceptible aphids.

The application of aphid control by Acrostalagmus aphidum in the field. Following our preliminary experiments in the green-house in December, 1926, field trial were effected in an effort to control the aphid Rhopalosipum persicae Sulzer on the eggplant. A plot intended for breeding purposes showed a severe infestation of the insects toward the latter part of that month. A suspension of the spores was prepared from cultures and from the dead bodies of the aphids. This was sprayed during a cool afternoon with an atomizer over the lower surfaces of the leaves where the aphids were feeding. The majority of the plants in alternate rows were treated in this manner. Only the aphids on a few of the leaves on each plant received the inoculum, as the treatment of all the leaves on each plant would have required too much labor and a considerable quantity of the spore suspension. The days following the inoculation were attended by cloucly weather with light intermittent rains. Under these conditions the fungus developed luxuriantly on the suseept insects. At the end of the first week the majority of the insects on the sprayed plants were dead. From these the inoculum was transported to the neighboring uninoculated plants and in fourteen days the infection of the insects had extended over the entire field. In less than three weeks the greater part of the aphids were parasitized by the fungus. The results were convineing. Control of the aphids in the field was possible by this simple method.

Three weeks later a short period of rains occurred. The weather was favorable for the multiplication of the aphids and therefore a new infestation eame about. No longer had the aphids begun to increase in numbers than infection of their bodies with the fungus ensued. The pathogene seemed to have lived in the soil and from here the inocula was transferred to the aphids. These results showed first, that only one inoculation of the aphids is required in a field, and second, that the fungus lives in some saprophytic manner in the soil.

Eggplant has been grown in this same field during the last two years, September-December, 1927 and 1928. In both years aphids have appeared during rainy periods. However, a recurrence of the aphid fungus held them in check each year. This is a lucky eireumstance since it indicates that once a field is inoculated with the fungus the latter may persist for a number of years. Our experience with the fungus covers only a period of three years and further 
observations should be made in succeeding years to verify its presenee or disappearance.

Our field experiments have been conducted on the eggplant alone. The encouraging results in this crop should give a start to more extensive trials on other crops. From his observations the writer is convinced that an equally successful control can be secured on the aphids of the melon, cucumber, okra and other erops. On such plants like the melon, eucumber and cabbage control is probably more effective because of the foliage being closer to the soil. The inoculation experiments discused previously point to a wide range of species and genera of aphids that are parasitized by the fungus, A good many of those species are of economical importance.

Control of aphids in the greenhouse.-Eggplant and cueumber have been grown in pots during 1927 and 1928 in the greenhouse where the 1926 experiments were made. The fungus seems to have existed in the soil during all the time sinee our earlier experiments of 1926, for infestations of the aphids were readily stopped by its parasitizing effect. The question has been raised whether the fungus will survive in an environment where fungicides have to be systematically applied. No fungicidles have been used in our greenhouse and no experiments have been planned with this point in mind, so that the question must await longer for its answer. It is only logical to expect that fungieides applied for the control of plant diseases will also hold the aphid parasite in check. Where frequent applicatious of sprays or fungicidal dusts are made the chances for the aphid fungus acting on its hosts will be lessened. However, it is hard to conceive that the pathogene will be eliminated from the soil unless treatments for the elimination of soil microorganisms are ap. plied. Invasions of the aplids during the intervals between sprayings will probably be reached to some degree by the fungus.

\section{SUMMARY}

1. A fungus, Acrostalagmus aphidum Oud., parasitizes aphids in Porto Rico. It had been reported as A. albus Preuss.

2. The size of the spores in the various natural strata is more or less uniform.

3. The size of the spores appears to be larger for those produced on the natural strata than those developing on oatmeal agax cultures.

4. There seems to be a wider range of length and width of spores on our form than on the A. aphidum Ond. deseribed in Saccardo's "Sylloge Fungorum". 
5. Some of the conidia become one-to several-septate prior to germination.

6. Conidia or head-like structures are produced on germinating spores.

7. Some young conidia germinate while still attached to the head or to the branch tips.

8. Spores germinate rapidly in sugar solutions.

9. Spores rapidly lose their germinating power when dried.

10. Experiments indicate a possible stimulating effect of aphid juices on germination and development of spores. There are probably variations in the degree of that influence, according to species.

11. The fungus grows best at reactions of $\mathrm{pH} 6.93$ to 7.93 .

12. So far as is known, Acrostalagmus aphidum attacks the aphids on 17 species of the higher plants. Of these 8 had been reported previously and the remaining 9 are new additions. Among these are important erop plants.

13. The aphids which may be parasitized comprise five different genera of which two are here first reported. Aphis pseudobrassicae is first here reported parasitized by the fungus.

14. The fungus does not parasitize the corn aphid under natural conditions.

15. The fungus has also been reported on the eggplant lace-bug, Corythaica monacha.

16. Acrostalagmus aphidum can be employed successfully and eheaply in the control of the aphids of the eggplant. The method will probably be effective in field control of the aphids of other vegetables.

17. The pathogene lives in greenhouse soil. No experiment proof is at hand which would demonstrate whether the fungus is eliminated by the application of fungicides used for the control of plant diseases.

The writer wishes to express his deep gratitude to Miss Edith M. Patch, Fntomologist of the Maine Agricultural Experiment Station who made the determination of some of the aphids and to Miss Vera K. Charles of the Bureau of Plant Industry, Washington, D. C., for valuable help in the specific determination of the fungus. $\mathrm{He}$ is also indebted to Dr. Mel. T. Cook for his suggestions and help in the preparation of the Manuscript.

\section{LITERATURE CI'TED}

1. Johnston, John R. Report of the pathologist. In Porto Rico Sugar Prod. Ass'n Exp. Sta. Third Ann. Rept. 1913: 22-24. 
2. -........... The entomogenous fungi of Porto Rico. PortoRico Bd. Com. Agr. Bul. 10: 9-33, pl. 1-9. 1915.

3. Jones, Thos. H. Aphides or plant-lice attacking sugar-cane in Porto Rico. Porto Rico Bd. Com. Agr. Bul. 11: 7-19, fig. 1-2. 1915.

4. Stevenson, John A. A check list of Porto Rican fungi and a host index. Porto Rico Dept. Agr. Jour. 2: 125-264. 1918.

5. Wolcott, George N. "Insectae Portoricensis." Porto Rico Dept. Agr. Jour. 7: 1-313. 1923.

6. Zwaluwenburg, R. R. van. Insects affecting coffee in Porto Rico. Jour. BcFit. 10: 513-517. 1917.

\section{EXPLANATION OF PLATES \\ PLATE XI}

Fig. 1. Spores of Acrostalagmus aphidum germinating in the juice of the Cryptostegia aphid. Drawn at the end of $61 / 2$ hours.

Fig. 2. Spores germinating in the juice of the Cyperus aphid. Drawn at the end of $6 \frac{1}{2}$ hours.

Fig. 3. Spores germinating in water. Drawn at the end of $61 / 2$ hours.

Fig. 4. Spores germinating in water. Drawn at the end of 15 hours.

Fig. 5. Germinating spores producing a structure similar to the appresoria of the anthracnoses. The figure on the left shows the structure has germinated with the production of a secondary spore.

Fig. 6. Spores germmating while still attached to the sporophore.

Fig. 7. A bulb or blister-like affair produced by the fungus and which behaves in germination like a spore.

Fig. 8. Formation of heads or conglutination of spores. All stages.

Fig. 9. Single spores produced at the tips of fertile hyplac.

Fig. 10. The types of branching of the fertile hyphae of A. aphidum.

\section{PLATE XII}

Fig. 11. The undersurface of a leaf of Abelmoschus esculentus showing the parasitized aphids.

Fig. 12. Portions of the leaf of fig. 11, magnified about twenty times to show tho colonies of A. aphidum on the dead bodies of aphids. 


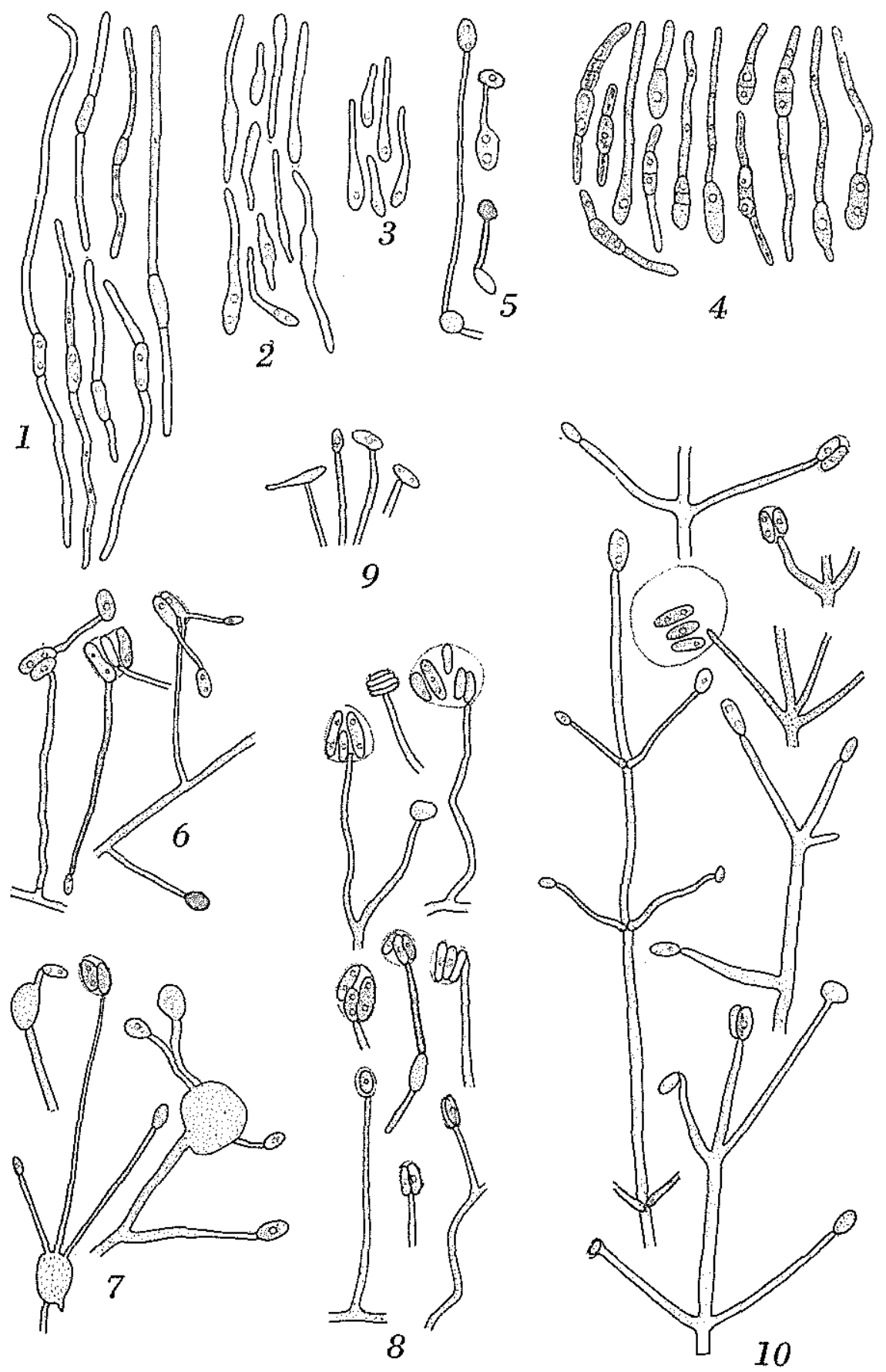



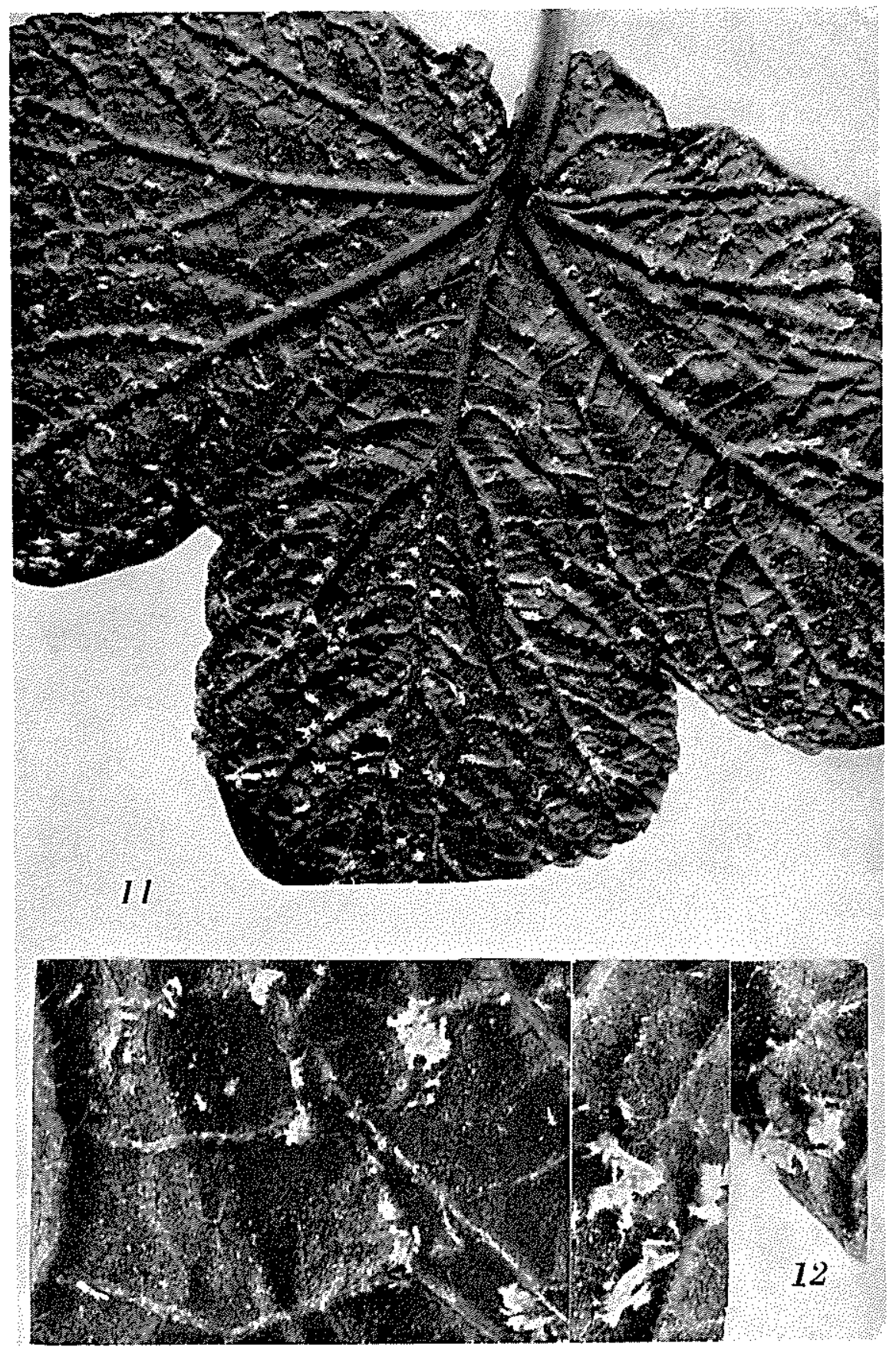